\title{
Surfaces
}

\section{Introduction to and Discussion Summary of William Tay's Colonialism, Cold War Era, and Marginal Space: The existential Conditions of Four Decades of Hong Kong Literature}

\section{Hendrik Birus}

Volume 5, 1995

DEUXIÈME CONGRÈS INTERNATIONAL SUR LE DISCOURS HUMANISTE (1995)

SECOND INTERNATIONAL CONFERENCE ON HUMANISTIC DISCOURSE (1995)

URI : https://id.erudit.org/iderudit/1064997ar

DOI : https://doi.org/10.7202/1064997ar

Aller au sommaire du numéro

Éditeur(s)

Les Presses de l’Université de Montréal

ISSN

1188-2492 (imprimé)

1200-5320 (numérique)

Découvrir la revue

Citer ce document

Birus, H. (1995). Introduction to and Discussion Summary of William Tay's Colonialism, Cold War Era, and Marginal Space: The existential Conditions of Four Decades of Hong Kong Literature. Surfaces, 5.

https://doi.org/10.7202/1064997ar
Résumé de l'article

Dans le cadre du deuxième congrès international sur le discours humaniste, ce texte est une introduction à " Colonialisme, guerre froide et espace marginal : les conditions d'existence de quatre décennies de la littérature à Hong Kong " de William Tay, et rapporte les principaux pôles d'intérêt qui ont émergé au cours de cette discussion.
Copyright @ Hendrik Birus, 1995

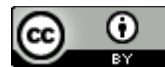

Ce document est protégé par la loi sur le droit d'auteur. L'utilisation des services d’Érudit (y compris la reproduction) est assujettie à sa politique d'utilisation que vous pouvez consulter en ligne.

https://apropos.erudit.org/fr/usagers/politique-dutilisation/ 


\section{Introduction to and Discussion Summary of William Tay's}

\section{Colonialism, Cold War Era, and Marginal Space: The existential Conditions of Four Decades of Hong Kong Literature}

Hendrik Birus

Universität München

birus@wiko-berlin.de

Surfaces Vol.V.205.1 (v.1.0A - 31/12/1995)

Copyright for texts published in SURFACES remains the property of authors. However, any further publication should be accompanied by an acknowledgement of SURFACES as the place of initial publication.

ISSN: $1188-2492$

\section{ABSTRACT}

In the context of the Second International Conference on Humanistic Discourse, this text introduces William Tay's "Colonialism, the Cold War Era, and Marginal Space: The Existential Conditions of Four Decades of Hong Kong Literature" and reports on the central concerns that emerged in its discussion.

\section{RÉSUMÉ}

Dans le cadre du deuxième congrès international sur le discours humaniste, ce texte est une introduction à «Colonialisme, guerre froide et espace marginal: les conditions d'existence de quatre décennies de la littérature à Hong Kong» de William Tay, et rapporte les principaux pôles d'intérêt qui ont émergé au cours de cette discussion.

In the following paper, Prof. Tay deals with the development of Hong Kong literature as a special case of humanistic discourse in East Asia.

To summarize this paper is in one respect very easy because it is so clearly written and well organized and full of information on Hong Kong literature, 
a fact for which I am very grateful. On the other hand, I see some difficulties integrating it into our frame of reference on humanistic discourse(s); so I'll need your help to relate it to our general subject. The specific claim of Prof. Tay's paper is outlined in the first sentence, namely, that the development of Hong Kong literature is arguably unique in the context of Britain's long history of global colonization. And the phrase "marginal space" in the title signals the point of conjunction with our last year's debates on the spaces between different languages and discourses and on their translatability and/ or intranslatability, as the case may be. Here, in this case, we are intrigued by the relationship between the development of a literature and the marginality of the area-or the free spaces between different areas-in which it emerges.

This process is particularly interesting because it took place under the practically laboratory conditions of a temporally and locally limited space: in the beginning a tiny location on the periphery of both the British Empire and China, later a bridgehead of the Cold War, finally becoming a privileged commercial center in the era of Détente. However, the literary discourse of Hong Kong could exist only because of the more or less open spaces between this marginal place and its changing political environments.

To elucidate the external conditions of the four decades of Hong Kong literature, Prof. Tay first of all poses the following question: "Why did the British colonial government not actively and wholeheartedly fight for and occupy this important public as well as private space of the superstructure?" For this kind of "enlightened form" of colonial administration culminating under the governorship of Murray MacLehose, Prof. Tay makes five assumptions: the unbroken tradition of Chinese literature, the continuity of China as a political entity, the unscathed national and cultural Chinese identity in Hong Kong under the British government, the traditional Chinese discrimination between Chinese and "barbarians," and the differentiated British approach to the divided India and to "leased" parts of China. And Prof. Tay makes reference to two additional factors in the specific development of Hong Kong: the Korean War and the Vietnam War.

But one very specific factor for the rise of Hong Kong literature forms the core of the paper: the role of newspaper literary supplements, tabloids, magazines, and the activities of publishing houses-differentiated into "those with foreign economic (and political) backgrounds, those formed by in-house writer groups and enjoying relative independence, and commercial groups aiming strictly at profit." So, peripheral to mainland China, to Taiwan, and-not to forget-to the Western World, the marginality of Hong Kong literature is that of "a local branch beyond the control of the center," but, on a more general level, "marginality" means that "serious literature is inevitably more and more marginalized." So we should ask if there is a connection between the two kinds of "marginality" of literature to be observed all over the world. But the paper ends with the ironical twist that it is just in the twilight period of Hong Kong that the British government first expresses a concern for literature! 


\section{Summary:}

The following discussion first dealt with the uniqueness of the situation of Hong Kong literature. Prof. Tay thus demonstrated how British colonial authorities vainly resisted the foundation of a Chinese university and, particularly, the establishment of political science at that university-now a distinguished home of the humanities. Examining the Hong Kong example, Prof. Iser emphasised "liminality" as a prime qualification of humanistic discourse: its reflecting capacity seems to depend on its extraterritorial status with respect to strict institutional commitments as well as nationalistic claims. In response to Prof. Lee's question as to the type of cultural identity constituted by the literary history of Hong Kong, Prof. Tay admitted the difficulty of theorizing with Habermas's, Jameson's, Lyotard's or other well known Western concepts about the situation of Hong Kong. But Prof. Lee and Prof. Iser insisted that theory does not necessarily have to be totalizing or harmonizing, but interventionist-and a good example for this could be Hong Kong.

Answering Prof. Wang's complementary questions on Hong Kong as a place for non-Chinese and its comparability to Singapore with respect to traditional Chinese culture, Prof. Tay argued that there was no substantial interchange with Western visitors, especially not with leftist writers who merely used the place as a stepping stone to the People's Republic of China. On the other hand, as distinguished from the simplification of Chinese characters and the dominance of British culture in Singapore (a topic elaborated upon by Prof. Krieger in the follow-up discussion), Hong Kong is far more traditional than mainland Kanton, and the British government did not want to interfere here-Manchu law, for example, was first abolished in the seventies. But the intricate difficulty with respect to teaching Chinese literature was reflected in the syllabus for high schools: too much could encourage nationalism, too little could diminish the chances for vivid writing independent of the communist literature in mainland China. And indeed, since the seventies one can observe an increasing sense of identification with Hong Kong and a decline in the cultural ties to Taiwan as well as to China.

The last part of the discussion dealing with the twilight situation of Hong Kong today these days was opened by Prof. Karatani's question as to whether any precedents existed for this unique situation. Prof. Tay argued that no Western theories on colonialism and post-colonialism really apply to the spiritual negotiations under way between current Hong Kong reality, Western technology, Chinese tradition, and the communist system of mainland China. Somewhere between anxiety and prophecy, a wait-and-seeapproach could be observed with the ultimate hope of autonomy for Hong Kong whose current cultural situation was reflected in a series of final remarks on high schools and universities, TV programs and museums, rock music and journalism-from the perspective that popular culture from Hong Kong is invading mainland China more and more, with the result that the margin is gaining the upper hand over the center. This formed the climax of an exciting discussion which, nonetheless, occasionally lost sight of the framework subject of humanistic discourse and its specificity in East Asia. 